\title{
Palliative care in Brasil: present and future
}

\author{
(iD) Cledy Eliana dos Santos ${ }^{1,2,5}$ \\ (D) Luciana Silveira Campos ${ }^{1,6}$ \\ (iD) Newton Barros ${ }^{1}$ \\ (iD) José Américo Serafim ${ }^{4}$ \\ (iD) Daniel Klug 3 \\ Ricardo Pedrini Cruz ${ }^{1}$
}

\begin{abstract}
1. Palliative Care and Pain Services. Hospital Nossa Senhora da Conceição - Conceição Hospital Group - Porto Alegre, Brasil 2. Community Health Service - Conceição Hospital Group - Porto Alegre, Brasil

3. Research and Education Management - Conceição Hospital Group - Porto Alegre, Brasil

4. Department of Informatics of the Single Health System - Ministry of Health - Brasília, Brasil 5. Research Center on Health Services and Technologies - Faculty of Medicine of the Porto University - Porto, Portugal
\end{abstract} 6. Public Health Institute of the Porto University - Faculty of Medicine of the Porto University - Porto, Portugal

http://dx.doi.org/10.1590/1806-9282.65.6.796

\section{SUMMARY}

OBJECTIVE: To estimate the human resources and services needed to meet the demand of the Brazilian population who would benefit from palliative care, based on the population growth projection for 2040.

METHODS: Population and mortality estimates and projections were obtained from the Brazilian Institute of Geography and Statistics. Service needs were estimated based on literature data.

RESULTS: The expected increase in the Brazilian population for $2000-2040$ is $37.5 \%$. The minimum estimate of patients with palliative care needs was 662,065 in 2000 and 1,166,279 in 2040. The staff required for each hundred thousand inhabitants would increase from 1,734 to 2,282, the number of doctors needed would increase from 4,470 to 6,274, and the number of nurses from 8,586 to 11,294, for the same period.

CONCLUSION: The definition of a national strategy predicting the increasing palliative care needs of the population is necessary. The expansion of the support network for chronic and non-transmissible diseases is necessary, but the training of existing human resources at all levels of attention to perform palliative actions can be a feasible alternative to minimize the suffering of the population.

KEYWORDS: Palliative care. Hospice care. Terminal care.

\section{INTRODUCTION}

Chronic non-communicable diseases (CNCD) are the primary causes of death worldwide, corresponding to $70 \%$ of all deaths (40 million people each year). Approximately 80\% of these deaths occur in low- and middle-income countries. ${ }^{1}$ In Brasil, CNCDs correspond to approximately $74 \%$ of the total number of deaths. Between 2008 and 2015, the four CNCDs prioritized by the World Health Organization (WHO) were circulatory diseases, cancer, respiratory diseases, and diabetes, which accounted for $60 \%$ of all deaths recorded in the Mortality Information System - Single Health System. ${ }^{2}$

DATE OF SUBMISSION: 11-Jan-2019

DATE OF ACCEPTANCE: 09-Feb-2019

CORRESPONDING AUTHOR: Cledy Eliana dos Santos

Avenida Francisco Trein, 596, Porto Alegre - RS, Brasil - CEP 91350-200

Phone: +55513357 2140 - Fax: +5551 32551744

E-mail: cledy.eliana@gmail.com 
Due to the characteristics of the CNCDs, patients often evolve to conditions under which there is no possibility of cure, with a prognosis of death in about a year, requiring palliative care $(\mathrm{PC})^{3}$ to manage the suffering caused by the disease and improve the quality of life. ${ }^{4.5}$ Although the evidence suggesting that patients with chronic non-neoplastic diseases require end-of-life care, ${ }^{4}$ in most countries, PC is directed at patients with terminal neoplastic diseases with no therapeutic possibility of a cure. ${ }^{3.6}$

The PC model comprises some measures to be taken well before the final stage of the disease. ${ }^{5}$ PC requires early identification, assessment, impeccable management of pain and other problems of physical, psychosocial, and spiritual nature in the period close to death. ${ }^{3}$ Ideally, PC should juxtapose the curative treatments in cases of poor prognosis, in a patient-centered integral approach, taking into account existential, psychosocial, and clinical needs. ${ }^{5}$ Several studies have been conducted to estimate the population in need of palliative care. ${ }^{7-12}$ Usually, these needs are estimated using epidemiological approaches or by evaluating the use of these services by the population. The epidemiological approach uses cause-specific mortality from diseases that would benefit from PC, per type and frequency of symptoms patients would probably experience at the end of life. This method is useful to identify all patients in palliative care because it does rely on the provision of services. $^{10}$

The first measurement of PC needs in Brasil was presented more than a decade ago, comparing the mortality data registered in 2004 with international parameters. ${ }^{13}$ A recent Brazilian publication that used the national registry of deaths and hospital admissions of 2014 and included all adults who died in that year estimated that between $24.6 \%$ and $85.2 \%$ of the patients who died of CNCD would have had an indication for PC, depending on the method used. ${ }^{14}$ The authors concluded that the method closest to the Brazilian reality would be the one that estimates that $57.2 \%$ of 11 of the patients who died of CNCD would have had an indication for PC, which would amount to 702,195 patients. ${ }^{14}$

The objective of this study is to estimate the human resources and the structure of services required, as well as the number of patients who would benefit from PC, using the projection of Brazilian population growth for 2040 and the parameters for estimates of PC needs proposed in the literature.

\section{METHODS}

\section{Demographic Database}

The population data for 2000-2015 and projections of population growth and mortality for 20162040 were obtained from the website of the Brazilian Institute of Geography and Statistics (IBGE). ${ }^{15}$ The mortality data for 2000-2015 were obtained from the Mortality Information System of the Single Health System (SIM-SUS). ${ }^{2}$ The variables used to generate the SIM-SUS tables were Chapters of the International Classification of Diseases, deaths per household, during 2000-2015. ${ }^{16}$

\section{Criteria for:}

1) Estimate of the population with palliative care needs

The basis of calculation for the population that would benefit from PC was the absolute number of deaths per year. ${ }^{2.15}$ The minimum proportion of patients was $57.2 \%$ of the number of deaths, based on what is proposed by Murtagh et al. ${ }^{11}$, and the maximum was $85.2 \%$ of the total number of deaths, based on the proposal by McNamara et al. ${ }^{12}$

\section{2) Estimate of the number of hospital beds}

The basis of calculation for the number of hospital beds needed to assist people in PC were the population data for 2000-2015 and estimates of population growth for 2016-2040 by the IBGE. ${ }^{15}$ The estimate was performed based on the parameters of the United Kingdom, ${ }^{17.18}$ also used in Portugal: 45 hospital beds for every million inhabitants. ${ }^{19}$

\section{3) Estimate of the type of hospital beds}

The basis of calculation was the number of hospital beds needed to assist people in PC (45 hospital beds for every million inhabitants) ${ }^{9,18,19}$, and the estimate of type of hospital bed was performed as proposed in the literature: $30 \%$ of the beds in general hospitals, $50 \%$ in an institution of medium and long stay, and $20 \%$ of the beds in homes or support homes. ${ }^{9,19,20}$

\section{4) Estimate of the number of inpatient units}

The basis of calculation for the number of inpatient units necessary to assist people in PC was the number of hospital beds needed for that population. It was considered that the units should have between 10-15 beds, based on estimates from the literature. ${ }^{19}$ 


\section{5) Estimate of the of staff needed}

The basis of calculation for the staff needed to assist people in PC were the population data for 2000-2015 and estimates of population growth for 2016-2040 by the IBGE. ${ }^{15}$ We considered the need for a staff of primary care/home care for every 100-150 thousand inhabitants, according to the criteria established in the literature. ${ }^{19.20}$

\section{6) Need for professionals with $P C$ training in Brasil}

The basis of calculation for the number of professionals with PC training needed for assistance was based on population data for 2000-2015 and estimates of population growth for 2016-2040 by the IBGE.${ }^{15}$ For the estimate of the number of doctors, we considered the proposed 25-30 doctors per million inhabitants. The basis for calculating the number of nurses was the estimate of the number of hospital beds needed. We used as a criterion the proposal of 1 to 1.2 nurses for each hospital bed. ${ }^{19}$

\section{7) Data protection and ethical issues}

The research project was approved by the Research Ethics Committee of the Conceição Hospital Group under the number 533.468, on 05/02/2014, thus complying with the ethical criteria for human research of the 466/2012 Resolution of the Ministry of Health. The need for a Free and Informed Consent Form was waived because we used free-access data by the Ministry of Health, not linked to any patient identification.

\section{RESULTS}

The projection of the Brazilian population for $2000-2040$ by the IBGE ${ }^{15}$ shows a growth of $31.5 \%$. Figure 1 presents the population data for 20002015 , projections of the population for 2016-2040, ${ }^{15}$ the mortality rates for 2000-2015 from the SIMSUS, $^{2}$ the estimate of mortality for 2016-2040 by the IBGE, ${ }^{15}$ and the minimum and maximum estimates of the population that would benefit from PC during 2000-2040. ${ }^{11.12}$

Table 1 shows the number of inpatient units, staffs, doctors, and nurses for the care of patients with palliative care needs. The inpatient units should have between 10 and 15 beds, and a staff of primary care/home care should be organized for every 150 thousand inhabitants. ${ }^{18.19}$ In the table, we present the arithmetic average between the minimum and maximum numbers of units estimated according to the number of beds in each one of them. For the year 2000, the average projection was 624 units, and for 2040, the projection was a total of 821 inpatient units. The number of staffs of primary care/home care needed to meet the demand of the population ranged from 1,156 in 2000 to 1,521 in 2040. In 2000, there was a need for approximately 4,770 doctors and 8,586 nurses. For the year 2040 , a total of 6,274 doctors and 11,294 nurses would be needed for the care of patients with PC needs.

The distribution of beds was made according to the following: while for the year 2000 an average of 7,805 beds was estimated $-2,342$ in general hospitals, 3,903 in institutions of medium/long stay, and 1,561 in support homes -, for 2040, 10,267 hospital beds would be necessary $-3,080$ beds in general hospitals, 5,133 in units of medium/long stay, and 2,053 in support homes.

\section{DISCUSSION}

The objective of this study was to analyze the needs of PC based on demographic data and projections of population growth and mortality of the Brazilian population. There are several estimates and parameters developed to estimate the PC needs of a given population, and there is no consensus among authors about which is the most appropriate..$^{\mathbf{8 1 0 , 1 2 , 1 9}}$ Using the criterion that seemed most appropriate for the Brazilian population, ${ }^{11}$ in the year 2020, 765,855 people would have an indication for PC in Brasil.

Another study by this group examined 1.7 million hospital admissions in Brasil of patients under ICD10 (Code of the International Classification of Diseases - 10) ${ }^{20}$, "clinical complications for the treatment of cancer" and the network available for patients in PC. In Brasil, it is estimated that $90 \%$ of these hospitalizations are related to a possible indication for PC. Between 2008 and 2016, there were 1.7 million hospital admissions under this CID, distributed among 3,374 health units in Brazilian territory, 91\% of them in 380 hospitals. In December 2016, there were 115 institutions providing PC registered at the National Academy of Palliative Care. Seventy-nine percent were hospital units, $12.3 \%$ were clinics/health centers, $4.7 \%$ were home care services, and 3.8 corresponded to university leagues. ${ }^{21}$ The installed capacity is far from meeting the needs of the population today.

Palliative care treats death as a natural process of 
FIGURE 1. POPULATION WITH PALLIATIVE CARE NEEDS BASED ON POPULATION ESTIMATES IN BRASIL - PORTO ALEGRE, 2017.

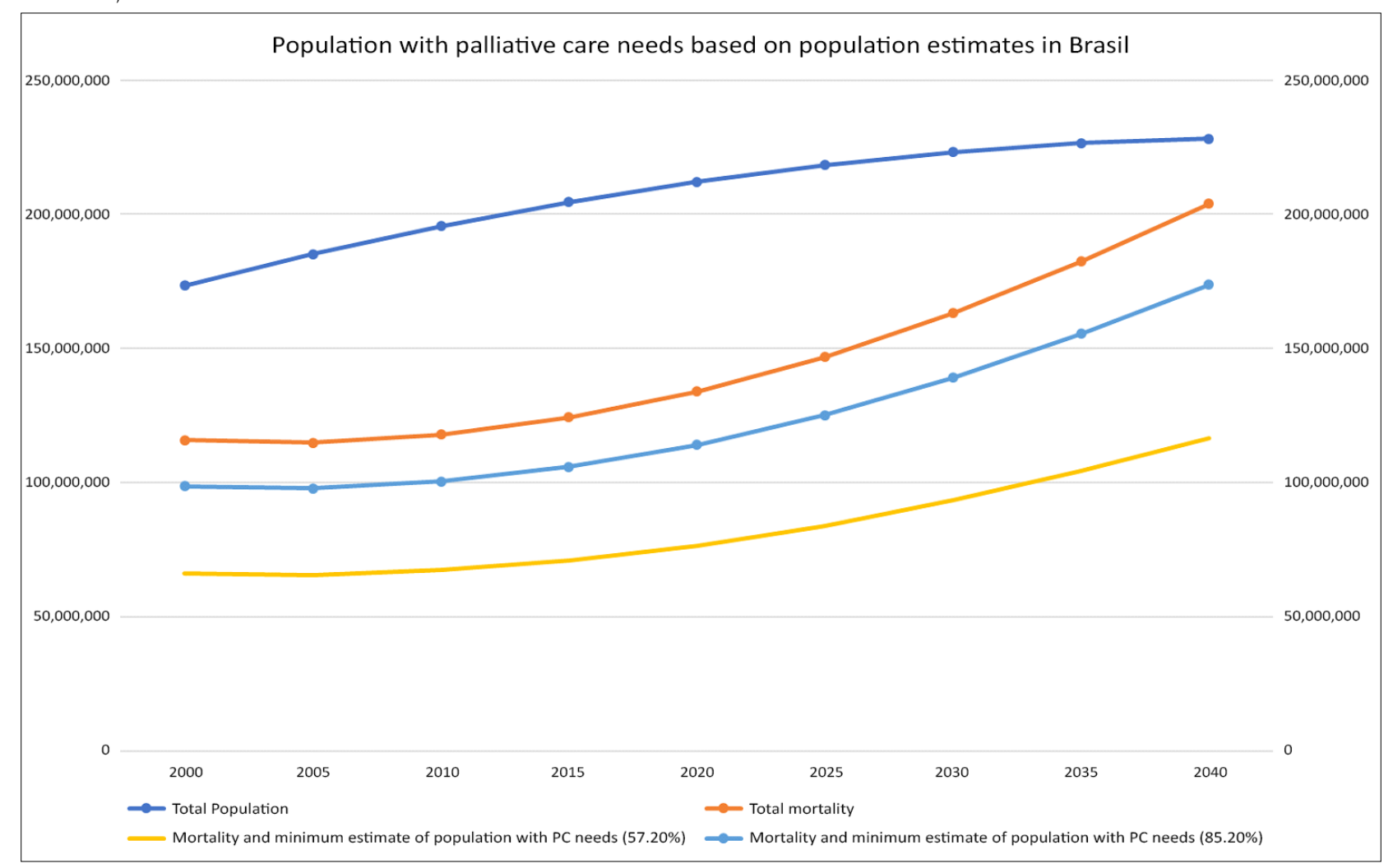

TABLE 1. ESTIMATE OF INPATIENT UNITS, STAFFS OF PRIMARY CARE/HOME CARE, DOCTORS, AND NURSES FOR PALLIATIVE CARE IN BRASIL - PORTO ALEGRE, 201718.19

\begin{tabular}{|c|c|c|c|c|}
\hline & Care Units & $\begin{array}{l}\text { Staffs of primary } \\
\text { care/home care }\end{array}$ & Doctors & Nurses \\
\hline Year & Beds/Unit $^{\star}$ & $\begin{array}{l}1 / 150 \text { thousand } \\
\text { inhabitants }\end{array}$ & $\begin{array}{l}20-25 / \\
\text { million } \\
\text { inhabitants }\end{array}$ & 1-1.2/bed \\
\hline 2000 & 624 & 1,156 & 4,770 & 8,586 \\
\hline 2005 & 667 & 1,234 & 5,092 & 9,165 \\
\hline 2010 & 704 & 1,303 & 5,376 & 9,677 \\
\hline 2015 & 736 & 1,363 & 5,622 & 10,120 \\
\hline 2020 & 763 & 1,414 & 5,832 & 10,497 \\
\hline 2025 & 786 & 1,456 & 6,004 & 11,045 \\
\hline 2030 & 803 & 1,488 & 6,136 & 10,807 \\
\hline 2035 & 815 & 1,510 & 6,227 & 11,209 \\
\hline 2040 & 821 & 1,521 & 6,274 & 11,294 \\
\hline
\end{tabular}

* Arithmetic average between the minimum and maximum number of units estimated.

life, with no intention to postpone or hasten it. Its objective is to relieve the pain and other distressing symptoms. It integrates psychological, social, and spiritual aspects in the care of the patient, provides a support network so that the patient can live as actively as possible until their death, and supports the family during the mourning process. ${ }^{22}$ Moreover, studies suggest that the survival of patients under PC with neoplasia is equal to or even greater than patients who receive curative treatment until the end of life, with better scores for quality of life ${ }^{23.24}$. In addition, PC is cost-effective, ${ }^{24.25}$ which justifies the investment in service structures and human resources. Currently, the training of human resources and the provision of services are a challenge in countries of medium and high income that already have a more organized network, in comparison with that of Brasil, to serve the population. $., 18,19,26$

\section{CONCLUSION}

Given the aging of the population and the increased life expectancy, a national strategy foreseeing care needs becomes imperative. Although it is necessary to expand health care networks, the training of already existent human resources on all levels of care, which are capable of spreading the concept of PC across their workplaces of activity and perform palliative actions, would likely be a feasible alternative to alleviate the suffering of the population affected by progressive and incurable diseases after its evolution makes it irreversible. 


\section{RESUMO}

OBJETIVO: Estimar as necessidades de recursos humanos e serviços necessários para o atendimento de pacientes que se beneficiariam de cuidados paliativos a partir da projeção de crescimento da população brasileira até 2040.

MÉTODO: As estimativas e projeções populacionais e de mortalidade foram obtidas nos dados do Instituto Brasileiro de Geografia e Estatística e do Sistema Único de Saúde. As estimativas de estrutura de serviços e recursos humanos foram realizadas a partir de dados da literatura.

RESULTADOS: A expectativa de aumento da população brasileira entre 2000 e 2040 é de 31,5\%. A estimativa mínima de pacientes com necessidades de cuidados paliativos foi de 662.065 em 2000 e é de 1.166 .279 em 2040 . O número de equipes necessárias para cada 100 mil habitantes passaria de 1.734 para 2.282 no mesmo período; o número de médicos foi de 4.770 para 6.274 e o número de enfermeiros necessários para atender as demandas dessa população foi de 8.586 para 11.294 nesse espaço de tempo.

CONCLUSÃO: A definição de uma estratégia nacional prevendo a necessidade de cuidados crescentes da população se torna necessária. A expansão da rede de assistência a doenças crônicas e não transmissíveis se mostra necessária, porém a capacitação de recursos humanos já existentes em todos os níveis de atenção para desempenhar ações paliativas pode ser uma alternativa factível para minimizar o sofrimento da população.

PALAVRAS-CHAVE: Cuidados paliativos. Cuidados paliativos na terminalidade da vida. Assistência terminal.

\section{REFERENCES}

1. World Health Organization. Palliative care: fact sheet [Internet]. 2015 [cited 2017 Nov 21]. Available from: http://www.who.int/mediacentre/factsheets/fs402/en/

2. Brasil. Ministério da Saúde. DATASUS. Informações de Saúde. Mortalidade Brasil [Internet]. Brasília; 2015 [cited 2017 Nov 21]. Avaliable from: tabnet.datasus.gov.br/cgi/deftohtm.exe?sim/cnv/obt10uf.def

3. Queiroz ACCM, Mota DDCF, Bachion MM, Ferreira ACM. Úlceras por pressão em pacientes em cuidados paliativos domiciliares : prevalência e caraterísticas. Rev Esc Enferm USP. 2014;48(2):264-71.

4. The SUPPORT Principal Investigators. A controlled trial to improve care for seriously ill hospitalized patients. The study to understand prognoses and preferences for outcomes and risks of treatments (SUPPORT). JAMA. 1995;274(20):1591-8.

5. Martín-Lesende I, Recalde E, Viviane-Wunderling P, Pinar T, Borghesi F, Aguirre $T$, et al. Mortality in a cohort of complex patients with chronic illnesses and multimorbidity: a descriptive longitudinal study. BMC Palliat Care. 2016;15:42

6. McClung |A. End-of-life care in the treatment of heart failure in older adults. Heart Fail Clin. 2017;13(3):633-44.

7. Gómez-Batiste X, Martínez-Muñoz M, Blay C, Amblàs |, Vila L, Costa X, et al. Utility of the NECPAL CCOMS-ICO ${ }^{\circ}$ tool and the surprise question as screening tools for early palliative care and to predict mortality in patients with advanced chronic conditions: a cohort study. Palliat Med. 2017;31(8):754-63.

8. Higginson IJ, Hart S, Koffman J, Selman L, Harding R. Needs assessments in palliative care: an appraisal of definitions and approaches used. I Pain Symptom Manage. 2007;33(5):500-5.

9. Stjernswärd |, Foley KM, Ferris FD. The public health strategy for palliative care. J Pain Symptom Manage. 2007;33(5):486-93.

10. Franks PJ, Salisbury C, Bosanquet N, Wilkinson EK, Lorentzon M, Kite S, et al. The level of need for palliative care: a systematic review of the literature. Palliat Med. 2000;14(2):93-104

11. Murtagh FE, Bausewein C, Verne J, Groeneveld El, Kaloki YE, Higginson IJ. How many people need palliative care? A study developing and comparing methods for population-based estimates. Palliat Med. 2014;28(1):49-58.

12. McNamara B, Rosenwax LK, Holman CD. A method for defining and estimating the palliative care population. I Pain Symptom Manage. 2006;32(1):5-12

13. Maciel M. Organização de serviços de cuidados paliativos. In: Carvalho $\mathrm{R}$, Parsons H, orgs. Manual de cuidados paliativos [Internet]. $2^{\mathrm{a}}$ ed. Rio de Janeiro: Diagraphic; 2009. p.72-85. [cited 2017 Nov 21] Available from: http://biblioteca.cofen.gov.br/wp-content/uploads/2017/05/Manual-de-cuidados-paliativos-ANCP.pdf
14. Santos CE, Caldas JMP, Serafim JA, Barros N, Pereira AC, Capra MEZ et al. Palliative care in Brazil: with a view to future needs? Int Arch Med. 2017;10(148):1-9. [cited 2017 Nov 21]. Available from: http://imedicalsociety.org/ojs/index.php/iam/article/view/2440/2143

15. Instituto Brasileiro de Geografia e Estatística - IBGE. Projeção da população [Internet]. 2013 [cited 2017 Jan 1]. Available from: ftp://ftp.ibge.gov. br/Projecao_da_Populacao/Projecao_da_Populacao_2013/nota_metodologica_2013.pdf

16. Centro Colaborador da OMS para a Classificação de Doenças em Português -. Classificação estatística internacional de doenças e problemas relacionados à saúde - CID-10 [Internet]. [cited 2017 lan 22]. Available from: http://www.datasus.gov.br/cid10/V2008/cid10.htm

17. Lupu D; American Academy of Hospice and Palliative Medicine Workforce Task Force. Estimate of current hospice and palliative medicine physician workforce shortage. | Pain Symptom Manage. 2010;40(6):899-911.

18. Finlay I. UK strategies for palliative care. I R Soc Med. 2001;94(9):437-41.

19. Portugal. Comissão Nacional de Cuidados Paliativos. Plano estratégico para o desenvolvimento dos cuidados paliativos: biênio 2017-2018 [Internet]. Lisboa: Comissão Nacional de Cuidados Paliativos; 2017 [cited 2017 Nov 21]. Available from: https://www.sns.gov.pt/wp-content/uploads/2016/09/Plano-Estrat\%C3\%A9gico-CP_2017-2018-1.pdf

20. Gómez-Batiste X, Pascual A, Espinosa J, Caja C. Design, implementation and evaluation of palliative care public health programs. Med Clin (Barc). 2010;135(4):179-85

21. Santos CE, Caldas P, Serafim JM, Barros N, Pereira AC, Capra MEZ, et al. Availability of palliative care cancer services in Brazil. methaodos. Rev Ciencias Soc. 2017;5(2):341-54

22. Araújo MMT, Silva MIP. A comunicação com o paciente em cuidados paliativos: valorizando a alegria e o otimismo. Rev Esc Enferm USP. 2007;41(4):668-74.

23. Temel JS, Greer JA, Muzikansky A, Gallagher ER, Admane S, Jackson VA, et al. Early palliative care for patients with metastatic non-small-cell lung cancer. N Engl J Med. 2010;363(8):733-42.

24. Wright AA, Zhang B, Ray A, Mack IW, Trice E, Balboni T, et al. Associations between end-of-life discussions, patient mental health, medical care near death, and caregiver bereavement adjustment. JAMA. 2008;300(14):166573

25. Zhang B, Wright AA, Huskamp HA, Nilsson ME, Maciejewski ML, Earle $C C$, et al. Health care costs in the last week of life: associations with endof-life conversations. Arch Intern Med. 2009;169(5):480-8.

26. Boemer MR. Sobre cuidados paliativos. Rev Esc enferm USP. 2009:43(3):500-1. Available from: file:///C:/Users/valvocir04/Downloads/40384-Texto\%20do\%20artigo-47791-1-10-20120829.pdf 